Lorella Camellina

IUAV University of Venice,

Santa Croce 191 Tolentini, 30135 Venezia, Italy

lcamellina@iuav.it

\section{Venice Vega Park: history, "more media" and new narrative paradigms}

Established in Porto Marghera in 1992, Vega, the Venice Scientific and Technological Park (STP), aimed to be a research and innovation hub and an instrument for the reclamation and urban regeneration of the city's former industrial district. Vega forms a cluster of approximately 60 companies today but still, it is not viewed as the innovation landmark it was supposed to be, ostensibly because of its past reputation. In 2016 various local stakeholders decided to set up a multidisciplinary research group (IUAV and Ca' Foscari) with the primary purpose of reactivating the Park. The work explores the role that, in this context, Information Design and Data Visualization may serve in conceiving a new narrative paradigm to tell the evolution of the area in the form of an interactive application.The research drew on theoretical references and case studies claiming the disappearance of concepts such as old or new media in favor of the new "more media", and the cancellation of "design neutrality" in favor of visualizations based on specific datasets and representations (Manovich, 2008).

Indeed, the interactive application in question, accessible from a touch foil, allows to navigate three main section (photo database, treemap, data visualization) discovering different materials about Vega and their relationships (Lima, 2011). The choice of these materials resulted from the following steps. A preliminary analysis consisted in mapping historical sources on Porto Marghera. It revealed an abundance of documents that bears witness to the vibrancy of the area in the 


\section{ASSETS}

Interactive data visualization about VEGA's main contemporary assets: digital connectivity and accessibility by public transports.

\section{INFORMATION}

Button to access an overlay of

information about the section.

DATAVIZ ZOOM IN

From a six-hour visualization, to a

two-hour visualization.

\section{RETHORICS}

Treemap based on rethorics related to VEGA.

\section{EVOLUTION}

Database of selected historical

images retrieved from severa

archives.

\section{RESET}

It synchronizes the three sections of

the interface to the starting level.

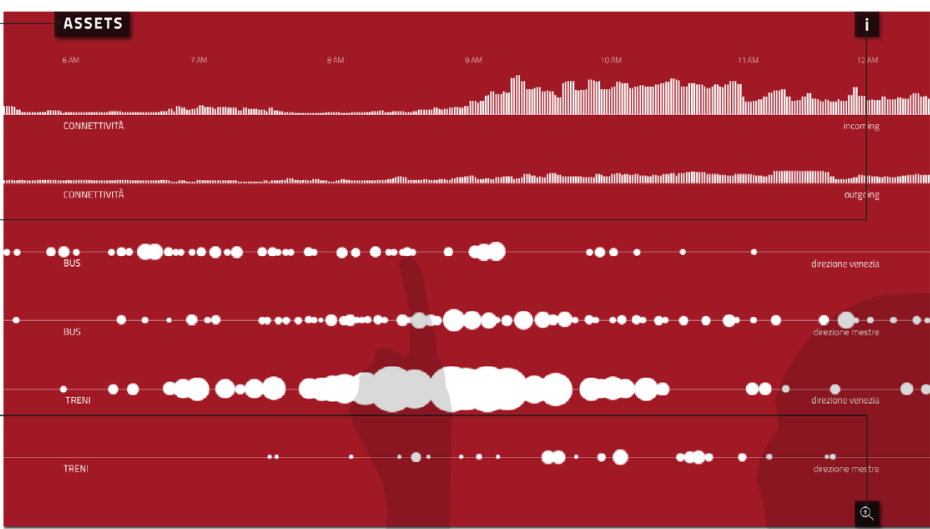

RETHORICS
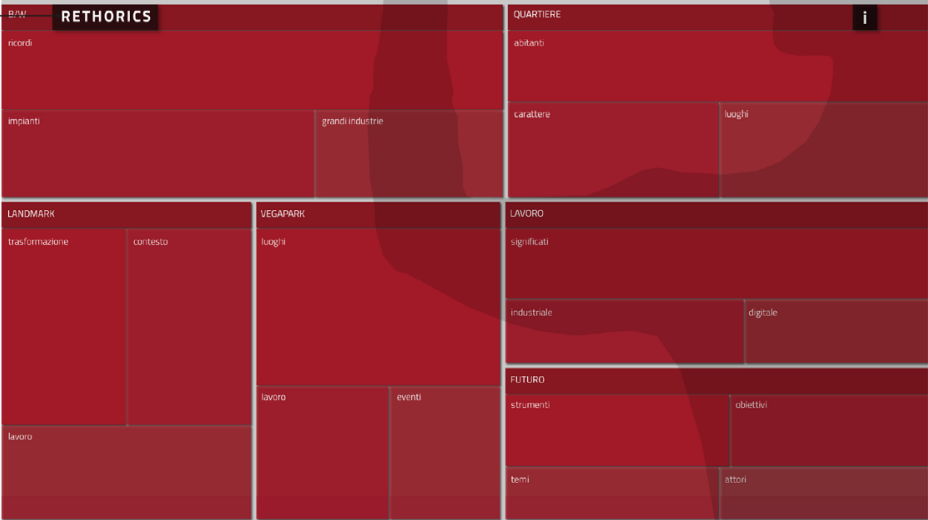

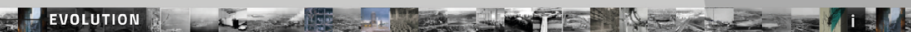

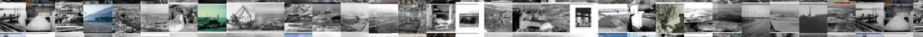

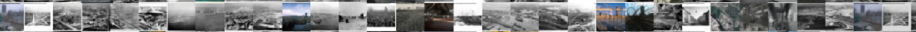

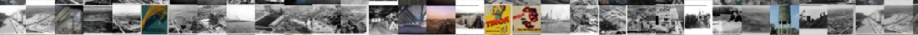

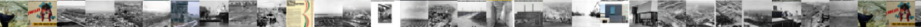
b. Fal

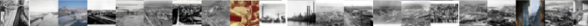

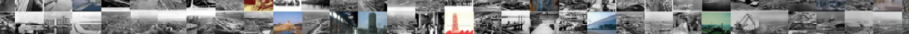
(1)

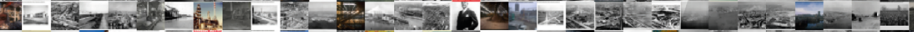

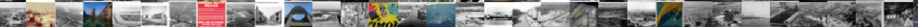

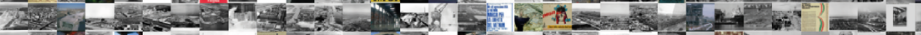

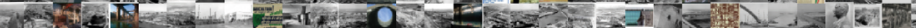

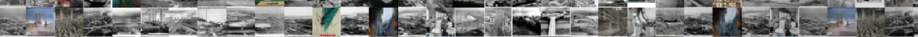

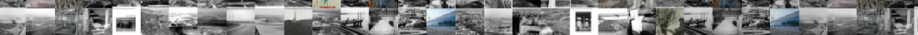

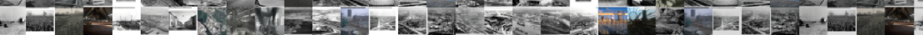

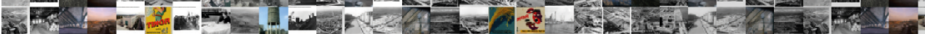

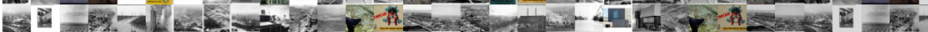
W.

$$
\mathrm{V}=G \mathrm{t}
$$

Fig. 1. The home screen of the interactive application, navigable from touch-foil support. 
twentieth century. What came to light is the absence of a single structure that can illustrate Venice's industrial past. The resources retrieved from the archives were skimmed in order to tell the historical transformations. The criteria applied to better address the overall project were two: the first to collect historical photographs to provide a visual story the local community could quickly empathize with; the second to consider images of industries that predated Vega as it exists today, to better understand the collective imagery that continues to be associated with the Park. Significant metadata (date, description, source and a few tags) were added to each image. It created a database of cultural objects related to the history of Vega: the first contribution to be included in the interface (LUST, McWilliams, Reas, 2010). Secondly, the study of the extensive bibliography about Porto Marghera highlighted many persisting rhetoric. Above all, the negative one stemming from a notorious past of poor working conditions, heavy pollution and workers' riots. The one that saw the separation of the area from its social value during the decommissioning of the industrial pole. The latest one for which the STP was the chance to activate innovative entrepreneurship. The research chose to reformulate a selection of these texts to be translated into visual treemaps through Text Mining. The goal was to display thematic groups of terms to reveal unusual semantic associations, explaining or subverting the existing rhetoric. It was the second form of "datization" used in order to tell the Park (Cukier, Mayer-Schönberger,
2013). Lastly, a detailed investigation of Vega's current situation pointed out the existence of aspects that can enable the development of a contemporary digital working scenario. Indeed, the STP boasts an excellent broadband connection (up to $300 \mathrm{Mbps}$ ) and a strategic geographical location in Italy's northeastern infrastructural network. Vega is easily accessible by public and private transportation, and is appealing to digital companies. Numerical and statistical datasets were retrieved to substantiate and make visible these positive assets (i.e. interactive datasets on digital connectivity, statistics about people traveling to and from Vega by train or bus, parking statistics, etc.). The translation of them into data visualization formed the third section of the application.

Building on these materials, the design intent was to develop a new narrative paradigm of Vega. Translating cultural artifacts into data means activating new ways of understanding reality, hindered so far by the absence of adequate technologies (Manovich, 2008). The interactive application is seen as a modern tool to structure, discover and add value to visual materials concerning Vega, offering an original way of understanding its complexity. In conclusion, in the case of Vega "datization" makes it possible to structure the visual imagery related to the history of the Park, finally making it accessible to a wider audience (Bruno, 2016). This new narrative paradigm seeks to dispel the fear of clinging to the past so that Vega may finally look to the future. 


\section{Book}

Cukier, K., Mayer-Schönberger, V., (2013). Big Data: una rivoluzione che cambierà il nostro modo di vivere e già minaccia la nostra libertà. Milan, Italy: Garzanti Libri.

Hessler, J., (2015). Map. Exploring the world. London, UK: Phaidon.

Lima, M., (2011). Visual complexity. Mapping patterns of information. New York, New York: Princeton Architectural Press.

LUST, McWilliams, C., Reas, C., (2010). Form+Code in Design, Art, and Architecture. New York, New York: Princeton Architectural Press.

Lupi, G., Posavec, S., (2016).

Dear Data. New York, New York:

Princeton Architectural Press.

Volli, U., (1994). II libro della

comunicazione. Milan, Italy: Il Saggiatore. from https://goo.gl/ZzZCVM.

Manovich, L., (2008). Introduction to Info-Aesthetics. Retrieved from https://goo.gl/1Pv4jB.

Manovich, L., (2012). Museum without walls, art history without names: visualization methods for humanities and media studies. Retrieved from https://goo.gl/drUpAi.

Manovich, L., (2015). Exploring urban social media: Selfiecity and On Broadway. Retrieved March 01, 2017 from https://goo.gl/vPfX7A

\section{Journal paper}

Ciracì, F., (2013). Mitologie 2.0: digital platforms and umbrella terms. $\mathrm{H}$-ermes. Journal of Communication (1), 109-126. Retrieved from https://goo.gl/CsFqv7.

Costa, P., (2016). Human-Data Experience Design: progettare con $\mathrm{i}$ personal data. MD Journal (2), 12-23. Retrieved from https://goo.gl/bGNQJM.

\section{Website article}

Avanzi Sostenibilità Per Azioni srl, et al., Community hub. I luoghi puri impazziscono. (2016) Retrieved from https://goo.gl/5TbQ2e.

Bruno, N., (2016). Interactive News Stories, what's next? Retrieved 